\title{
Internal politics block proposal by Russians to create foundation for basic research
}

\begin{abstract}
Moscow. Two years of negotiations aimed at founding a Russian analogue of the US National Science Foundation (NSF) seem for the time being to have got nowhere. The plan, advocated by Boris Saltykov, the Russian minister of science, was to create a National Foundation for Fundamental Research (NFFR). But the scheme is now in danger of foundering over disputes about how it should be run.

The history of the foundation is instructive. It is two years since Igor Nikolaev, formerly a researcher, became an official of the Russian State Committee for Science and Higher Education with responsibility for the formation of Russian foundations. Persuaded that most preexisting foundations were merely pots of money dispensed by administrative fiat, that supervisory expert committees were either nonexistent or were used to cloak administrative decisions in respectability and that the institution of peer review and the concept of conflict of interest do not exist in Russia, Nicolaev and two colleagues set out to draft the constitution of a Russian foundation that would function "properly".
\end{abstract}

After nearly a year and a half, they produced the papers for a foundation very similar to NSF. There was to be a scientific council, with authority divided between its president and a board of directors headed by a chief executive. Applications for funds would be scrutinized by committees of four experts.
To prevent the corruption of the appraisal process by the clannish Russian scientific community, expert appraisals were to be made public, referees were to be selected from a suitable database and foreign experts were to be involved. Nicolaev says the procedures for submitting applications and for accounting for funds spent were adaptations to Russian conditions of arrangements familiar in the West.

Towards the end of last year, the Carnegie Foundation of New York, which had seen the proposals, was talking of transferring a substantial sum of money to the foundation. But then the Soviet Union fell apart. When the wheels started turning again, and there was a presidential decree ready to sign, everything came to a halt again. The Ministry of Science (the post-putsch successor of the State Committee on Science and Higher Education) said there were so many pressing problems that the decree should be "more generalized".

So began another round of paper-chasing. The Carnegie money went elsewhere. The very idea of the foundation seemed to be an illusion ... . But then a miracle happened. On 27 April, President Boris Yeltsin signed a decree whose first item authorized the creation of the foundation as a self-governing entity. It also urged the recovery of Russian fundamental science and channelled 2 per cent of all Russia's spending on research to the foundation.

\section{Indian court bans quotas that give share of science posts to outcasts}

New Delhi. An Indian high court has ruled that reserving positions for socially backward castes in government jobs and university science and medical programmes is illegal and a violation of the Indian constitution. The judgement by the Allahabad high court of Uttar Pradesh, India's biggest state, overturns existing policy that sets aside 22 per cent of the jobs and university admissions slots to those in the lower castes. The judge declared that science has no religion or caste and that "there can therefore be no valid reservation in the field of science and technology".

The current policy tries to balance the need for technical excellence with the obligation to make special provisions for those from educationally and socially disadvantaged classes. Although he said that backward classes must be helped, the judge ruled that the interests of the nation are paramount. "The time has come when it must be boldly and clearly stated that there can be no compromise in the field of science and technology", he wrote in his decision.

The ruling is a response to a suit filed by a college chemistry lecturer from an upper caste who was ordered to vacate his position to make room for someone from a lower caste. The court invited the lecturer to remain and asked the college to pay his salary.

The caste issue is controversial in India. Two years ago, a suggestion by the prime minister that the quota be raised to 40 per cent triggered riots by students in which 35 people died. Although the ruling is not binding on other states, it is expected to shape judicial decisions throughout India.

K.S. Jayaraman
Sadly, the story does not end there. Yeltsin went on to appoint as president of the foundation Andrei Gonchar, the wellliked first vice-president of the Russian Academy of Sciences (RAS) and a natural candidate for the post. But when Gonchar held his first meeting with Nikolaev in mid-May, he made it plain that he sees the foundation in a very different light.

Gonchar said he did not fancy Nikolaev as executive director of the foundation and that there was no need for such a post. Nor was a scientific council necessary. Moreover, Gonchar objected to the condition that the presidency must be a full-time appointment, saying that he would not resign as vice-president of the RAS.

How this business will be decided is not yet clear. There is an obvious danger in the NFFR ending up as an adjunct of the RAS, which is responsible for only half of the fundamental research conducted in Russia. Or there may be another round of paperchasing. The newly born foundation may become one of the best foundations in the world, but for now it exists only on paper.

Vladimir Pokrowsky

\section{Italian peer review under pressure}

Milan. Sandro Fontana this week becomes Italy's new minister for research at a time when most Italian scientists think the system funding them is unfair. One of the first demands on him will be a request from Luigi Rossi-Bernardi, president of the Italian research council (CNR), to change the rules governing the review of grant proposals to bring the CNR more into line with the rest of Europe. Responding to pressure from dissatisfied scientists, Rossi-Bernardi has agreed to ask the government to reconsider a system that 'doesn't know how to say no' — giving small grants to most applicants but large grants to no-one.

The CNR has ten committees that oversee funding in all areas of science. Each has around 15 members, most of whom are university professors elected every fouryears by the scientific community. Although democratic, the system does not produce a formal peer review system within the committees. Elected members feel a responsibility to their voters, and therefore award money on the basis of who holds the power within a university as well as on scientific merit. Rossi-Bernardi says that he would like to preserve the democratic element of committee elections while broadening the pool of reviewers.

Alison Abbott 